\title{
Akurasi Arah Kiblat Masjid - Masjid di Kota Kendari
}

\author{
Jabal Nur dan Nur Azizah Huzaimah
}

Fakultas Syariah, Institut Agama Islam Negeri (IAIN) Kendari, Indonesia

\author{
jabalnur@iainkendari.ac.id
}

\begin{abstract}
Abstrak
Penelitian ini membahas tentang akurasi arah kiblat masjid-masjid di kota Kendari. Penelitian ini didasari dugaan bahwa beberapa masjid di kota Kendari tidak akurat arah kiblatnya. Ketidakakuratan itu ditengarai karena cara menentukan akurasi arah kiblat yang tidak tepat atau menngunakan metode tradisonal. Adapun permasalahan dalam penelitian ini adalah bagaimana cara masyarakat menentukan arah kiblat masjid-masjid di kota Kendari dan bagaimana solusi masjid-masjid yang tidak akurat arah kiblatnya. Tujuan penelitian ini adalah untuk mengetahui cara masyarakat menentukan arah kiblat dan solusi bagi masjid-masjid yang sudah dibangun. Penelitian ini adalah penelitian lapangan, pengumpulan datanya adalah observasi dan wawancara, teknik analisis datanya adalah metode deskriptif eksploratif. Hasil penelitian menunjukkan bahwa cara masyarakat menentukan arah kiblat dengan metode tradisional mengakibatkan 14 masjid dari 20 masjid yang menjadi obyek penelitian arah kiblatnya tidak akurat/melenceng/tidak mengarah ke Ka'bah. Solusi bagi masjid masjid yang tidak akurat arah kiblat agar melakukan pengukuran ulang tanpa merubuhkan masjid yang sudah ada.
\end{abstract}

Kata Kunci: Akurasi, Arah Kiblat

\section{Abstract}

This study discusses the accuracy of the direction of the mosques in the city of Kendari. This research is based on the allegation that several mosques in Kendari city are not accurate in their Qibla direction. The inaccuracy was suspected because of the way to determine the accuracy of the Qibla direction that was not right or to use traditional methods. The problem in this research is how the community determines the direction of the mosques in the city of Kendari and how the solutions of the mosques are not accurate the direction of the Qibla. The purpose of this study is to find out how the community determines the direction of Qibla and solutions for mosques that have been built. This research is field research, the data collection is observation and interview, the data analysis technique is descriptive exploratory method. The results showed that the way the community determined the direction of Qibla with the traditional method resulted in 14 mosques out of 20 mosques being the object of the Qibla direction being inaccurate / deviated / did not lead to the Kaaba. Solutions for mosques that are 
not accurate direction of Qibla in order to re-measure without tearing down the existing mosque.

\section{Keywords: Accuracy, Qibla Direction}

\section{A. Pendahuluan}

Shalat merupakan salah satu bentuk interaksi antara hamba dengan Allah swt. Oleh karena itu seorang hamba yang ingin berinteraksi dengan Allah melalui shalat harus memperhatikan beberapa hal, diantaranya harus suci badan, pakaian dan tempat serta menghadap kiblat. Abdul Aziz Dahlan ${ }^{1}$ mengemukakan bahwa "salah satu syarat sahnya shalat adalah menghadap kiblat, kiblat adalah arah Ka'bah ke Mekkah Arab Saudi. Setelah hijrah ke Madinah Nabi Muhammad saw menetapkan Yerusalem sebagai kiblat, namun kemudian dialihkan ke Mekkah.

Khafid" $^{2}$ menjelaskan bahwa "kiblat adalah jarak terdekat menuju kakbah melalu graet circle pada waktu mengerjakan ibadah shalat. Kakbah atau Baitullah adalah sebuah bangunan suci yang merupakan pusat berbagai peribadatan kaum umat muslim ytang terletak di kota Mekkah.

Pernyataan di atas menunjukkan bahwa kiblat sangat penting kedudukannya sehingga metode penentuan arah kiblatpun ikut berkembang sesuai dengan perkembangan zaman mulai dari metode tradisional hingga kontemporer. Tujuan perhitungan arah kiblat pada dasarnya adalah untuk mengetahui ke arah mana Ka'bah di Mekkah itu dilihat dari suatu tempat dipermukaan bumi, sehingga semua gerakan orang yang sedang melaksanakan shalat, baik ketika berdiri, rukuk, maupun sujudnya selalu berimpit dengan arah yang menuju Ka'bah.

Berbagai teori untuk mengukur arah kiblat secara akurat telah ditemukan, namun masyarakat dalam menentukan arah kiblat masih banyak

${ }^{1}$ Abdul Aziz Dahlan, 2005, Ensiklopedia Silam, PT. Ichtiar Varu vann Hoeve, Jakarta.

${ }^{2}$ Khafid, 2009, Penentuan Arah Kiblat, Skripsi, Makalah Pelatihan Penentuan Arah Kiblat, Cibinong. 
yang menggunakan cara-cara tradisonal seperti menentukan arah kiblat dengan melihat dimana matahari terbenam. Ada juga yang menentukan arah kiblat dengan berpatokan pada masjid yang terdekat tanpa perhitungan terlebih dahulu. Observasi awal penulis menemukan ada beberapa masjid di kota Kendari yang tidak akurat arah kiblatnya, seperti Masjid Rumah Sakit Bahteramas dan Masjid Baitul Izzah. Dugaan penulis masih ada masjid-masjid yang lain yang tidak akurat arah kiblatnya. Berdasarkan hasil observasi awal tersebut penting untuk dilakukan penelitian karena menyangkut peribadatan umat muslim dan penulis dapat memberi sumbangsih positif terkait dengan penentuan akurasi arah kiblat masjid-masjid di kota Kendari.

\section{B. Metode Penelitian}

Penelitian ini adalah penelitian lapangan dimana peneliti langsung secara aktif pada objek penelitian yaitu masjid-masjid di kota Kendari. Adapun pendekatan yang digunakan dalam penelitian ini adalah pendekatan sosiologis atau kajian hukum yuridis emperis untuk menjawab pertanyaan-pertanyaan tentang metode menentukan arah kiblat oleh pengelola masjid-masjid di kota Kendari. Penelitian dilakukan di masjid-masjid di kota Kendari dan telah dilaksanakan selama satu bulan.

Alat pengumpulan data dalam penelitian ini adalah observasi, wawancara, studi dokumen, dan sampel. Peneliti mewawancarai para pengelola masjid di kota Kendari, sedangkan sampel dalam penelitian ini peneliti mengambil sebanyak 20 masjid dari 365 masjid yang ada di kota Kendari. Metode analisis data yang digunakan adalah metode deskriptif eksploratif. Sedangkan metode pengecekan keabsahan datanya menggunakan triangulasi. 


\section{Pembahasan}

\section{Metode Penentuan Arah Kiblat}

Penentuan arah kiblat dapat dilakukan dengan dua metode yaitu:

a) Metode pengukuran taqribi (menggunakan acuan perkiraan)

Metode ini adalah metode yang paling sederhana karena cukuk dengan mengetahui titik mata angin yang utama yakni, Utara, Selatan, Barat dan Timur. Dengan pengetahuan arah mata angin utama tersebut, maka dimana letak Kakbah dari tempat pengukuran cukup memudahkan karena akan diketahui apakah arah tersebut telah lurus, atau miring ke kanan, atau kekiri, dan juga dapat megetahui seberapa besar angka kemiringannya. Penerapan metode taqribi membutuhkan beberapa alat antara lain:

1) Pisau Silet

Pisau silet berguna untuk menemukan posisi arah Utara dan arah selatan. Setelah arah utara dan selatan diketahui, elanjutnya tinggal membuat garis tegak lurus terhadap garis Utara dan Selatan, maka didapatlah titik Barat dan titik Timur. ${ }^{3}$

2) Kompas

Kompas terdiri dari tiga macam, yaitu: ${ }^{4}$

a) Kompas transparan

Kompas diletakkan pada bidang datar yang telah ditentukan titik Utara dan Titik Selatan. Titik pusat kompas berada dititik pusat perpotongan garis Utara, Selatan, Barat dan Timur, jarum kompas tepat mengarah ke Utara, lalu kompas diputar sebesar sudut yang dicari. Setelah kompas

${ }^{3}$ Sirril Wafa, dkk, 2015, Akurasi Arah Kiblat Masjid dan Mushallah di Wilayah Ciputat", Laporan Penelitian, Fakultas Syariah dan Hukum UIN Syarif Hidayatullah, Jakarta, hlm. 17.

${ }^{4}$ A. Jamil, 2009, Ilmu Falak Teori dan Aplikasih, Cet. I, Amzah, Jakarta, hlm. 121. 
diputar dan jarum kompas telah tepat pada derajat sudut yang dicari, diberi tanda atau titik, maka itulah arah kiblat.

b) Kompas Magnetik

Kompas diletakkan pada bidang datar yang telah ditentukan titik Utara dan titik Selatan. Titik pusat kompas berada di titik pusat perpotongan garis Utara, Selatan, Barat dan Timur, jarum kompas tepat mengarah ke Utara, lalu kompas diputar sebesar sudut yang dicari. Setelah kompas diputar dan jarum kompas (kcl) telah tepat pada derajat sudut yang dicari, maka itulah arah kiblat.

c) Kompas Kiblat

Kompas kiblat merupakan alat yang sangat mudah digunakan untuk menentukan arah kiblat suatu tempat, sebab dengan meletakkan kompas tersebut pada jarumnya akan secara otomatis mengarah atau menunjukkan arah kiblat yang dicari. Tekniksnya sama dengan kompas transparan dan kompas magnet, bedanya kompas tidak perlu diputar.

3) Busur Derajat (Rubu' Mujayyab)

Langkah-langkah penggunaan busur derajat sebagai berikut: ${ }^{5}$

a) Membuat atau menetukan titik pada garis Utara dan Selatan, misalkan titik U untuk Utara dan S untuk Selatan.

b) Dengan menggunakan siku, Buat Garis yang tegak lurus dengan garis Utara dan Selatan, yaitu Garis Barat dan Timur., misalkan titik B untuk Barat dan T untuk Timur.

c) Pada titik pusat perpotongan, misalkan menjadi titik A. 
d) Busur derajat yang telah disiapkan titik pusatnya diletakkan pada titik A dan memanjang mengikuti garis Utara dan Selatan (berimpit).

e) Titik $90^{\circ}$ pada busur tepat dititik Utara, sedangkan titik $0^{\circ}$ dan $180^{\circ}$ berimpit dengan titik Barat dan Timur.

f) Hitung mulai dari $90^{\circ}$ sampai berapa besar derajat yang akan dicari arah kiblatnya, lalu beri titik, misalkan titil Q. Hubungkan Titik A dengan titik Q. Garis A-Q adalah kiblataa yang dicari.

4) Tongkat Istiwa'

Langkah-langkah penggunakan tongkat istiwa adalah sebagai berikut: ${ }^{6}$

a) Tegakkan sebuah tongkat (kayu atau besi) yang lurus sepanjang 1,5 meter atau lebi tegak lurus ke bumi, diatas tempat terbuka dan tidak terhalang oleh sinar matahari sepanjang hari.

b) Buat beberapa lingkaran pusat sekeliling tongkat tersebut, titik pusat lingkaran tersebut berhimpit dengan tempat berdirinya tongkat.

c) Perhatikan saat banyang-bayang ujung tongkat menyentuh lingkaran, pada pagi hari (sebelum dhuhur) dan sore hari (sesudah dhuhur), lalu beri tanda titik. Jadi ada dua titik pada masingmasing lingkaran tersebut, yaitu titik pada waktu pagi dan titik pada waktu sore.

d) Hubungkan kedua titik tersebut dengan menggunakan sebuah garis lurus, dan inilah garis Barat dan Timur.

e) Dari titik Barat selanjutnya digeser sedikit kearah kanan, disitulah ditentukan arah kiblatnya. hlm. 99.

${ }^{6}$ Encup Supriatna, 2007, Hisab Rukyat dan Aplikasinya, PT. Refika Aditama, Bandung, 


\section{5) Rashdul Kiblat}

Rashdul kiblat adalah ketentuan waktu di mana bayangan benda yang terkena sinar matahari menuju ke arah kiblat. ${ }^{7}$ Dalam pengertian lain adalah saat dimana posisi matahari berada tepat di atas Kakbah. Dengan demikian arah jatuhnya bayangan benda yang terkena cahaya matahari itu adalah kiblat.

Menurut Susikna Azhari ${ }^{8}$, adapun cara sederhana mengecek arah kiblat menggunakan metode ini adalah sebagai berikut:

a) Letakkan satu tegakkan (tongkat dan sejenisnya) di tempat yang terkena cahaya matahari.

b) Amati jatuhnya bayangan tersebut yang terbentuk oleh cahaya matahari.

c) Tentukan arah jatuhnya bayangan itu sebagai arah kiblat.

b) Metode Pengukuran Tahqiqi (Menggunakan Metode Pengukuran yang Akurat)

1) Teodolit

Alat ukur sudut digital yang paling akurat untuk mengukur arah kiblat adalah Teodolit. Untuk mendapatkan hasil pengukuran yang akurat maka dibutuhkan data yang akurat pula. Data titik koordinat suatu tempat yang digunakan dalam penentuan arah kiblat sebaiknya diperoleh dari GPS (Global Positioning System). ${ }^{9}$ GPS merupakan sebuah alat penerima informasi waktu dan posisi secara pasti dan benar karena menggunakan data satelit yakni kode tertentu yang dikirimkan oleh satelit ke penerima GPS. ${ }^{10}$

${ }^{7}$ Izzuddin, Ahmad, 2012, Metode Penetuan Arah Kiblat dan Akurasinya, AICIS, IAIN Sunan Ampel, Surabaya, hlm. 45.

${ }^{8}$ Susiknan Azhari, 2004, Ilmu Falak Teori dan Praktek, Cet.ke - 1, Suara Muhammadiyah, Yogyakarta.

${ }^{9}$ Ibid., hlm. 785.

${ }^{10}$ Abidin Hasanudin Z, 2001, Geodesi Satelit, PT. Pradnya Paramita, Jakarta, hlm. 43. 
2) Ilmu Segitiga Bola (Spherical Trigonometri)

Mencari sudut arah kiblat dapat dilakukan dengan menggunakan rumus-rumus ilmu ukur segi tiga bola (Spherical Trigonometri).

\section{Cara Masyarakat Menentukan Arah Kiblat Masjid-Masjid di Kota} Kendari

Penentuan arah kiblat masjid-masjid di kota Kendari dilakukan oleh masyarakat atau pengurus masjid dengan berbagai cara atau metode. Secara umum masyarakat menentukan arah kiblat dengan menggunakan kompas, bayangan matahari dan perkiraan arah barat. Berikut ini peneliti menyajikan data masjid dan cara masyarakat menentukan arah kiblat secara rinci.

\section{Tabel 1.}

Data masjid yang penentuan arah kiblatnya menggunakan bayangan matahari

\begin{tabular}{|c|l|l|}
\hline No & \multicolumn{1}{|c|}{ Nama Masjid } & \multicolumn{1}{c|}{ Cara Menentukan Arah Kiblat } \\
\hline 1 & Amaliyah & Bayangan Matahari \\
\hline 2 & Masjid Raya Kota Lama & Bayangan Matahari \\
\hline 3 & At-Taqwa & Bayangan Matahari \\
\hline 4 & Nurul Falah & Bayangan Matahari \\
\hline 5 & Al- Muqarrabun & Bayangan Matahari (tongkat istiwa') \\
\hline
\end{tabular}

Sumber: Pengelola/Pengurus Masjid

Data di atas memberi informasi bahwa ada 5 masjid yang penentuan arah kiblatnya mengikuti bayangan matahari, dan 1 masjid mengikuti bayangan matahari dibantu dengan Tongkat Istiwa'. Pengurus masjid meyakini bahwa arah matahari terbit adalah barat dan terbenam adalah arah timur, sehingga muncul anggapan dimana matahari terbit disitulah kiblat. 
Tabel 2.

Data Masjid yang Penentuan Arah Kiblatnya dengan Kompas

\begin{tabular}{|c|l|c|}
\hline No & \multicolumn{1}{|c|}{ Nama Masjid } & Cara Menentukan Arah Kiblat \\
\hline 1 & At-Taqwa & Kompas \\
\hline 2 & Al-Jaariah & Kompas \\
\hline 3 & Quba Wirabuana & Kompas \\
\hline 4 & Al- Ikhlas & Kompas \\
\hline 5 & Mihftahul Jannah & Kompas \\
\hline 6 & Al-Mubarak & Kompas \\
\hline 7 & Nurul Husna & Kompas \\
\hline 8 & Lailatul Qadri & Kompas \\
\hline 9 & Nurul Jannah & Kompas \\
\hline 10 & Al- Mi'raj & Kompas \\
\hline 11 & Al- Ikhlas & Kompas \\
\hline
\end{tabular}

Sumber data: Pengelola/Pengurus Masjid

Data di atas memberi informasi bahwa ada 11 masjid yang penentuan arah kiblatnya menggunakan kompas. 10 masjid yang menggunakan kompas magnetik dan 1 masjid yang menggunakan kompas kiblat.

\section{Tabel 3.}

Data Masjid yang Penentuan Arah Kiblatnya dengan Perkiraan Arah Barat

\begin{tabular}{|c|l|l|}
\hline No & \multicolumn{1}{|c|}{ Nama Masjid } & \multicolumn{1}{c|}{ Cara Pengukuran } \\
\hline 1 & Fastabiqul Khairat & Arah barat \\
\hline 2 & Baburrahman & Arah barat \\
\hline 3 & Al- Ikhwan & Arah barat \\
\hline 4 & Babul Jihad & Arah barat \\
\hline
\end{tabular}


Sumber data: Pengelola/Pengurus Masjid

Data di atas memberi informasi bahwa 4 masjid tersebut arah kiblatnya ditentukan dengan cara hanya melihat arah barat tanpa melakukan pengukuran dengan metode bantuan yang lain.

Tabel 4.

Data Masjid yang Penentuan Arah Kiblatnya Menggunakan Teodolit

\begin{tabular}{|c|l|l|}
\hline No & \multicolumn{1}{|c|}{ Nama Masjid } & \multicolumn{1}{c|}{ Cara Pengukuran } \\
\hline 1 & Ruhul Iman & Teodolit \\
\hline
\end{tabular}

Sumber data: Pengelola/Pengurus masjid

Teodolit adalah alat yang digunakan unntuk mengukur sudut bidang horisontal dan vertikal, alat ini sangat membantu untuk menentukan keakurasian arah kiblat, yang mana dapat menghitung sudut dengan tepat.

Untuk mengetahui akurasi penentuan arah kiblat antara metode tradisional dan kontemporer, peneliti mengemukakan perbandingan hasil perhitungan menggunakan rumus ilmu ukur segi tiga bola dan google earth sebagai berikut:

a. Akurasi Arah Kiblat Masjid-masjid di Kota Kendari Dengan Mengunakan Rumus Ilmu Ukur Segi Tiga Bola.

Perhitungan arah kiblat di masjid-masjid kota kendari peneliti menggunakan metode tahqiqi yang dikerjakan melalui perhitungan matematis dengan menggunakan rumus Ilmu Ukur Segitiga bola (Spherical Trigonometri). Data-data yang dihasilkan dalam perhitungan ini adalah mengetahui lintang dan bujur tempat dimana masjid didirikan dan mengetahui lintang dan bujur Kakbah. Untuk mengetahui lintang dan bujur maka penulis menngunakan GPS 
(Global Posisioning System) yaitu alat ukur koordinat dengan menggunakan satelit.

Setiap masjid memiliki sedikit perbedaan letak koordinat, adapun data koordinat masing-masing masjid adalah sebagai berikut:

Tabel 5.

Lintang dan Bujur Masjid di Kota Kendari

\begin{tabular}{|c|c|c|c|}
\hline No & Nama Masjid & Lintang & Bujur \\
\hline 1 & Amaliyah & $3^{\circ} 58^{\prime} 35^{\prime \prime} \mathrm{LS}$ & $122^{\circ} 35^{\prime} 48^{\prime \prime} \mathrm{BT}$ \\
\hline 2 & Masjid Raya Kota Lama & $3^{\circ} 58^{\prime} 17^{\prime \prime} \mathrm{LS}$ & $122^{\circ} 35^{\prime} 13^{\prime \prime} \mathrm{BT}$ \\
\hline 3 & At-Taqwa & $3^{\circ} 58^{\prime} 8^{\prime \prime} \mathrm{LS}$ & $122^{\circ} 34^{\prime} 25^{\prime \prime} \mathrm{BT}$ \\
\hline 4 & Nurul Falah & $3^{\circ} 57^{\prime} 39^{\prime \prime} \mathrm{LS}$ & $122^{\circ} 31^{\prime} 52^{\prime \prime} \mathrm{BT}$ \\
\hline 5 & Al-Jaariah & $3^{\circ} 58^{\prime} 11 " \mathrm{LS}$ & $122^{\circ} 31^{\prime} 23^{\prime \prime} \mathrm{BT}$ \\
\hline 6 & Al- Muqarrabun & $3^{\circ} 57^{\prime} 50^{\prime \prime} \mathrm{LS}$ & $122^{\circ} 31^{\prime} 22^{\prime \prime} \mathrm{BT}$ \\
\hline 7 & Fastabiqul Khairat & $4^{\circ} 0^{\prime} 5^{\prime \prime} \mathrm{LS}$ & $122^{\circ} 33^{\prime} 2^{\prime \prime} \mathrm{BT}$ \\
\hline 8 & Quba Wirabuana & $4^{\circ} 0^{\prime} 32^{\prime \prime} \mathrm{LS}$ & $122^{\circ} 32^{\prime} 41^{\prime \prime} \mathrm{BT}$ \\
\hline 9 & Al- Ikhlas & $3^{\circ} 59^{\prime} 14^{\prime \prime} \mathrm{LS}$ & $122^{\circ} 34^{\prime} 57^{\prime \prime} \mathrm{BT}$ \\
\hline 10 & Baburrahman & $3^{\circ} 59^{\prime} 2^{\prime \prime} \mathrm{LS}$ & $122^{\circ} 35^{\prime} 40^{\prime \prime} \mathrm{BT}$ \\
\hline 11 & Mihftahul Jannah & $4^{\circ} 1^{\prime} 11^{\prime \prime} \mathrm{LS}$ & $122^{\circ} 30^{\prime} 2^{\prime \prime} \mathrm{BT}$ \\
\hline 12 & Al-Mubarak & $4^{\circ} 2^{\prime} 39^{\prime \prime} \mathrm{LS}$ & $122^{\circ} 28^{\prime} 53^{\prime \prime} \mathrm{BT}$ \\
\hline 13 & Nurul Husna & $4^{\circ} 18^{\prime} 33^{\prime \prime} \mathrm{LS}$ & $122^{\circ} 32^{\prime} 7 " \mathrm{BT}$ \\
\hline 14 & Al- Ikhwan & $4^{\circ} 1^{\prime} 17^{\prime \prime} \mathrm{LS}$ & $122^{\circ} 32^{\prime} 9 " \mathrm{BT}$ \\
\hline 15 & Lailatul Qadri & $3^{\circ} 59^{\prime} 47^{\prime \prime} \mathrm{LS}$ & $122^{\circ} 31^{\prime} 14^{\prime \prime} \mathrm{BT}$ \\
\hline 16 & Nurul Jannah & $3^{\circ} 59^{\prime} 15^{\prime \prime} \mathrm{LS}$ & $122^{\circ} 31^{\prime} 6^{\prime \prime} \mathrm{BT}$ \\
\hline 17 & Ruhul Iman & $3^{\circ} 57^{\prime} 55^{\prime \prime} \mathrm{LS}$ & $122^{\circ} 28^{\prime} 6^{\prime \prime} \mathrm{BT}$ \\
\hline 18 & Al- Mi'raj & $3^{\circ} 58^{\prime} 8^{\prime \prime} \mathrm{LS}$ & $122^{\circ} 29^{\prime} 9^{\prime \prime} \mathrm{BT}$ \\
\hline 19 & Al- Ikhlas & $4^{\circ} 0^{\prime} 31 " \mathrm{LS}$ & $122^{\circ} 30^{\prime} 0 " \mathrm{BT}$ \\
\hline 20 & Babul Jihad & $3^{\circ} 59^{\prime} 14^{\prime \prime} \mathrm{LS}$ & $122^{\circ} 30^{\prime} 9 " \mathrm{BT}$ \\
\hline
\end{tabular}

Sumber: GPS dan Google Earth 
Berdasarkan data koordinat masing-masing masjid di atas, untuk mendapatkan arah kiblatnya maka akan dihitung dengan menggunakan rumus sebagai berikut:

Busur a: Bila tempat itu berlintang Utara, maka besar busur a adalah $90^{\circ}$ dikurang derajat lintang daerah tersebut. Sedangkan bila tempat itu berlintang Selatan, maka besar busur a adalah $90^{\circ}$ ditambah derajat lintang daerah tersebut.

Busur b: Lintang Kakbah dihitung dari kutub Utara atau $90^{\circ}$ dikurang Lintang Kakbah.

Sudut c: Jika daerah yang ingin diketahui arah kiblatnya berada di Bujur Timur, maka besar nilai sudut $\mathrm{c}$ adalah Bujur daerah dikurang Bujur Kakbah. Sedangkan jika daerah yang ingin diketahui arah kiblatnya berada di Bujur Barat, maka sebaliknya.

Tabel 6.

Hasil Perhitungan Arah Kiblat Masjid-Masjid di Kota

Kendari yang Menjadi Objek Penelitian Berdasarkan Koordinat

\begin{tabular}{|c|c|c|c|c|c|}
\hline No & Nama Masjid & Lintang & Bujur & $\begin{array}{r}\text { Kiblat } \\
\text { (U-B) }\end{array}$ & $\begin{array}{r}\text { Kiblat } \\
\text { (B-U) }\end{array}$ \\
\hline 1 & Amaliyah & $3^{\circ} 58^{\prime} 35^{\prime \prime} \mathrm{LS}$ & $122^{\circ} 35^{\prime} 48^{\prime \prime} \mathrm{BT}$ & $68^{\circ} 2^{\prime} 2^{\prime \prime}$ & $21^{\circ} 57^{\prime} 58^{\prime \prime}$ \\
\hline 2 & Masjid Raya Kota Lama & $3^{\circ} 58^{\prime} 17^{\prime \prime} \mathrm{LS}$ & $122^{\circ} 35^{\prime} 13^{\prime \prime} \mathrm{BT}$ & $68^{\circ} 2^{\prime} 0^{\prime \prime}$ & $21^{\circ} 58^{\prime} 0^{\prime \prime}$ \\
\hline 3 & At-Taqwa & $3^{\circ} 58^{\prime} 8^{\prime \prime} \mathrm{LS}$ & $122^{\circ} 34^{\prime} 25^{\prime \prime} \mathrm{BT}$ & $68^{\circ} 2^{\prime} 15^{\prime \prime}$ & $21^{\circ} 57^{\prime} 45^{\prime \prime}$ \\
\hline 4 & Nurul Falah & $3^{\circ} 57^{\prime} 39^{\prime \prime} \mathrm{LS}$ & $122^{\circ} 31^{\prime} 52^{\prime \prime} \mathrm{BT}$ & $68^{\circ} 1^{\prime} 38^{\prime \prime}$ & $21^{\circ} 58^{\prime} 22^{\prime \prime}$ \\
\hline 5 & Al-Jaariah & $3^{\circ} 58^{\prime} 11^{\prime \prime} \mathrm{LS}$ & $122^{\circ} 31^{\prime} 23^{\prime \prime} \mathrm{BT}$ & $68^{\circ} 1^{\prime} 36^{\prime \prime}$ & $21^{\circ} 58^{\prime} 24^{\prime \prime}$ \\
\hline 6 & Al- Muqarrabun & $3^{\circ} 57^{\prime} 50^{\prime \prime} \mathrm{LS}$ & $122^{\circ} 31^{\prime} 22^{\prime \prime} \mathrm{BT}$ & $68^{\circ} 1^{\prime} 38^{\prime \prime}$ & $21^{\circ} 58^{\prime} 22^{\prime \prime}$ \\
\hline 7 & Fastabiqul Khairat & $4^{\circ} 0^{\prime} 5^{\prime \prime} \mathrm{LS}$ & $122^{\circ} 33^{\prime} 2^{\prime \prime} \mathrm{BT}$ & $68^{\circ} 1^{\prime} 39^{\prime \prime}$ & $21^{\circ} 58^{\prime} 21^{\prime \prime}$ \\
\hline 8 & Quba Wirabuana & $4^{\circ} 0^{\prime} 32^{\prime \prime} \mathrm{LS}$ & $122^{\circ} 32^{\prime} 41^{\prime \prime} \mathrm{BT}$ & $68^{\circ} 1^{\prime} 32^{\prime \prime}$ & $21^{\circ} 58^{\prime} 28^{\prime \prime}$ \\
\hline 9 & Al- Ikhlas & $3^{\circ} 59^{\prime} 14^{\prime \prime} \mathrm{LS}$ & $122^{\circ} 34^{\prime} 57^{\prime \prime} \mathrm{BT}$ & $67^{\circ} 25^{\prime} 40^{\prime \prime}$ & $22^{\circ} 34^{\prime} 20^{\prime \prime}$ \\
\hline 10 & Baburrahman & $3^{\circ} 59^{\prime} 2^{\prime \prime} \mathrm{LS}$ & $122^{\circ} 35^{\prime} 40^{\prime \prime} \mathrm{BT}$ & $68^{\circ} 1^{\prime} 59^{\prime \prime}$ & $21^{\circ} 58^{\prime} 1^{\prime \prime}$ \\
\hline 11 & Mihftahul Jannah & $4^{\circ} 1^{\prime} 11 " \mathrm{LS}$ & $122^{\circ} 30^{\prime} 2^{\prime \prime} \mathrm{BT}$ & $68^{\circ} 1^{\prime} 13^{\prime \prime}$ & $21^{\circ} 58^{\prime} 47^{\prime \prime}$ \\
\hline 12 & Al-Mubarak & $4^{\circ} 2^{\prime} 39^{\prime \prime} \mathrm{LS}$ & $122^{\circ} 28^{\prime} 53^{\prime \prime} \mathrm{BT}$ & $68^{\circ} 2^{\prime} 2^{\prime \prime}$ & $21^{\circ} 57^{\prime} 58^{\prime \prime}$ \\
\hline 13 & Nurul Husna & $4^{\circ} 18^{\prime} 33^{\prime \prime} \mathrm{LS}$ & $122^{\circ} 32^{\prime} 7^{\prime \prime} \mathrm{BT}$ & $67^{\circ} 59^{\prime} 57^{\prime \prime}$ & $22^{\circ} 0^{\prime} 3^{\prime \prime}$ \\
\hline 14 & Al- Ikhwan & $4^{\circ} 1^{\prime} 17^{\prime \prime} \mathrm{LS}$ & $122^{\circ} 32^{\prime} 9^{\prime \prime} \mathrm{BT}$ & $68^{\circ} 0^{\prime} 58^{\prime \prime}$ & $21^{\circ} 59^{\prime} 2^{\prime \prime}$ \\
\hline 15 & Lailatul Qadri & $3^{\circ} 59^{\prime} 47^{\prime \prime} \mathrm{LS}$ & $122^{\circ} 31^{\prime} 14^{\prime \prime} \mathrm{BT}$ & $67^{\circ} 59^{\prime} 40^{\prime \prime}$ & $22^{\circ} 0^{\prime} 22^{\prime \prime}$ \\
\hline
\end{tabular}




\begin{tabular}{|l|l|l|l|l|l|}
\hline 16 & Nurul Jannah & $3^{\circ} 59^{\prime} 15^{\prime \prime}$ LS & $122^{\circ} 31^{\prime} 6^{\prime \prime}$ BT & $68^{\circ} 1^{\prime} 29^{\prime \prime}$ & $21^{\circ} 58^{\prime} 31^{\prime \prime}$ \\
\hline 17 & Ruhul Iman & $3^{\circ} 57^{\prime} 55^{\prime \prime}$ LS & $122^{\circ} 28^{\prime} 6^{\prime \prime}$ BT & $68^{\circ} 2^{\prime} 2^{\prime \prime}$ & $21^{\circ} 57^{\prime} 58^{\prime \prime}$ \\
\hline 18 & Al- Mi'raj & $3^{\circ} 58^{\prime} 8^{\prime \prime}$ LS & $122^{\circ} 29^{\prime} 9^{\prime \prime}$ BT & $68^{\circ} 1^{\prime} 17^{\prime \prime}$ & $21^{\circ} 58^{\prime} 43^{\prime \prime}$ \\
\hline 19 & Al- Ikhlas & $4^{\circ} 0^{\prime} 31^{\prime \prime}$ LS & $122^{\circ} 30^{\prime} 0^{\prime \prime}$ BT & $68^{\circ} 1^{\prime} 16^{\prime \prime}$ & $21^{\circ} 58^{\prime} 44^{\prime \prime}$ \\
\hline 20 & Babul Jihad & $3^{\circ} 59^{\prime} 14^{\prime \prime}$ LS & $122^{\circ} 30^{\prime} 9^{\prime \prime}$ BT & $68^{\circ} 1^{\prime} 23^{\prime \prime}$ & $21^{\circ} 58^{\prime} 37^{\prime \prime}$ \\
\hline
\end{tabular}

Setelah diketahui sudut arah kiblat untuk masing-masing masjid, proses selanjutnya peneliti melakukan pengecekan langsung ke masjid-masjid untuk melihat keakuratan arah kiblat masjid dengan menggunakan liquid filled compas yaitu untuk melihat arah mata angin. Setelah ditemukan arah mata angin, maka penulis membuat ilustrasi dengan menggunakan busur kemudian peneliti menggambarkan arah kiblat yang akurat dan menghitung berapa kemiringan shaf yang ada di dalam masjid. Berdasarkan praktek langsung yang peneliti lakukan, maka didapatkan hasil sebagai berikut:

\section{Tabel 7.}

\section{Keakuratan Arah Kiblat Masjid-Masjid di Kota Kendari dengan}

Metode Perhitungan

\begin{tabular}{|l|l|c|}
\hline \multicolumn{1}{|c|}{ Nama Masjid } & Cara Menentukan Arah Kiblat & Keakuratan \\
\hline Amaliyah & Bayangan Matahari & $-18^{\circ}$ \\
\hline Masjid Raya Kota Lama & Bayangan Matahari & $+9^{\circ}$ \\
\hline At-Taqwa & Bayangan Matahari dan Kompas & Akurat \\
\hline Nurul Falah & Bayangan Matahari & $-21^{\circ}$ \\
\hline Al-Jaariah & Kompas & $-7^{\circ}$ \\
\hline Al- Muqarrabun & Bayangan Matahari (tongkat istiwa') & Akurat \\
\hline Fastabiqul Khairat & Arah barat & $-20^{\circ}$ \\
\hline Quba Wirabuana & Kompas & Akurat \\
\hline Al- Ikhlas & Kompas & $-5^{\circ}$ \\
\hline Baburrahman & Arah barat & $-7^{\circ}$ \\
\hline Mihftahul Jannah & Kompas & $-17^{\circ}$ \\
\hline Al-Mubarak & Kompas & $-9^{\circ}$ \\
\hline Nurul Husna & Kompas & $-26^{\circ}$ \\
\hline Al- Ikhwan & Arah barat & $-9^{\circ}$ \\
\hline Lailatul Qadri & Kompas & $-12^{\circ}$ \\
\hline Nurul Jannah & Kompas & \\
\hline
\end{tabular}




\begin{tabular}{|l|l|c|}
\hline Ruhul Iman & Teodolit & Akurat \\
\hline Al- Mi'raj & Kompas & Akurat \\
\hline Al- Ikhlas & Kompas & $-16^{\circ}$ \\
\hline Babul Jihad & Arah barat & $-24^{\circ}$ \\
\hline
\end{tabular}

Berdasarkan rumus perhitungan, diantara 11 masjid yang mengukur menggunakan kompas sebanyak 3 masjid yang akurat, diantara 5 masjid yang menggunakan bayangan matahari sebanyak 2 masjid yang akurat, dan 1 masjid yang menggunakan Teodolit juga akurat. Sedangkan sebanyak 4 yang masjid yang menggunakan perkiraan arah barat tidak ada satupun yang akurat arah kiblatnya/tidak tepat ke Ka'bah.

b. Akurasi Arah Kiblat Masjid-masjid di Kota Kendari dengan Menggunakan Google Earth

Peneliti melakukan pengecekan kembali kepada 20 masjid yang sebelumnya telah uji keakurasiannya dengan metode perhitungan, dan dari hasil pengecekan ulang maka penulis mendapatkan hasil sebagai berikut:

Tabel 8.

Keakuratan Arah Kiblat Masjid-Masjid di Kota Kendari dengan

Menggunakan Google Earth

\begin{tabular}{|c|l|c|c|c|}
\hline No & \multicolumn{1}{|c|}{ Nama Masjid } & $\begin{array}{c}\text { Arah Kiblat } \\
\text { yang tepat }\end{array}$ & $\begin{array}{c}\text { Arah Kiblat } \\
\text { masjid }\end{array}$ & Keakuratan \\
\hline 1 & Amaliyah & $291,97^{\circ}$ & $273,72^{\circ}$ & $-18,25^{\circ}$ \\
\hline 2 & Masjid Raya Kota Lama & $291,97^{\circ}$ & $300,87^{\circ}$ & $+8,9^{\circ}$ \\
\hline 3 & At-Taqwa & $291,97^{\circ}$ & $291,30^{\circ}$ & $-0,96$ Akurat \\
\hline 4 & Nurul Falah & $291,97^{\circ}$ & $270,95^{\circ}$ & $-21,02^{\circ}$ \\
\hline 5 & Al-Jaariah & $291,97^{\circ}$ & $284,52^{\circ}$ & $-7,45^{\circ}$ \\
\hline 6 & Al- Muqarrabun & $291,97^{\circ}$ & $291,90^{\circ}$ & $-0,07$ Akurat \\
\hline 7 & Fastabiqul Khairat & $291,97^{\circ}$ & $271,97^{\circ}$ & $-20^{\circ}$ \\
\hline 8 & Quba Wirabuana & $291,97^{\circ}$ & $291,44^{\circ}$ & $-0,53 \mathrm{Akurat}$ \\
\hline 9 & Al- Ikhlas & $291,97^{\circ}$ & $286,22^{\circ}$ & $-5,75^{\circ}$ \\
\hline 10 & Baburrahman & $291,97^{\circ}$ & $284,80^{\circ}$ & $-7,17^{\circ}$ \\
\hline
\end{tabular}




\begin{tabular}{|c|l|c|c|c|}
\hline 11 & Mihftahul Jannah & $291,98^{\circ}$ & $274,19^{\circ}$ & $-17,18^{\circ}$ \\
\hline 12 & Al-Mubarak & $291,97^{\circ}$ & $282,14^{\circ}$ & $-9,83^{\circ}$ \\
\hline 13 & Nurul Husna & $291,97^{\circ}$ & $265,30^{\circ}$ & $-26,67^{\circ}$ \\
\hline 14 & Al- Ikhwan & $291,97^{\circ}$ & $282,52^{\circ}$ & $-9,45^{\circ}$ \\
\hline 15 & Lailatul Qadri & $291,98^{\circ}$ & $292,93^{\circ}$ & $+0,95^{\circ}$ akurat \\
\hline 16 & Nurul Jannah & $291,98^{\circ}$ & $279,78^{\circ}$ & $-12,19^{\circ}$ \\
\hline 17 & Ruhul Iman & $291,98^{\circ}$ & $291,61^{\circ}$ & $-0,37$ Akurat \\
\hline 18 & Al- Mi'raj & $291,98^{\circ}$ & $291,98^{\circ}$ & Akurat \\
\hline 19 & Al- Ikhlas & $291,98^{\circ}$ & $275,34^{\circ}$ & $-16,64^{\circ}$ \\
\hline 20 & Babul Jihad & $291,98^{\circ}$ & $267,44^{\circ}$ & $-24,54^{\circ}$ \\
\hline
\end{tabular}

Berdasarkan data di atas, dari 20 masjid yang penulis teliti terdapat 6 masjid yang akurat dan 14 masjid yang masih melenceng atau menyimpang dari arah kiblat yang seharusnya. Masjid dengan penyimpangan tertinggi adalah $-26,67^{\circ} \mathrm{ke}$ arah Utara, dan Masjid dengan penyimpangan terendah adalah $-5,75^{\circ} \mathrm{ke}$ Utara.

\section{Analisis pada Permasalahan}

Secara umum, pendapat para ulama tentang kiblat dapat dibagi menjadi dua, yaitu arah kiblat bagi orang yang dapat melihat langsung Ka'bah adalah wajib menghadap ke Ka'bah ('Ain Ka'bah). Sementara para ulama berbeda pendapat tentang arah kiblat bagi orang yang tidak dapat melihat langsung Ka'bah, ada yang mewajibkan menghadap ke Ka'bah walaupun tidak mampu melihatnya secara langsung ('Ain Ka'bah) atau cukup menghadap ke arah Kakbah (Juhatul Ka'bah).

Imam Syafi'i berpendapat bahwa wajib menghadap ke bangunan Ka'bah secara tepat ketika mendirikan shalat, karena Allah mewajibkan untuk menghadap kiblat, maka wajib menghadap ke bangunan Ka'bah seperti halnya orang Mekkah. Menurut Imam Hanafi, bagi orang-orang yang jauh dari Ka'bah maka cukup menghadap Jihatul Ka'bah yaitu menghadap ke dinding-dinding atau mihrab yang dibangun dengan tanda- 
tanda yang menunjuk pada arah Ka'bah. Madzhab Maliki berpendapat bagi orang yang jauh dari Ka'bah dan tidak mengetahui arah kiblat secara pasti, maka cukup menghadap ke arah Ka'bah secara zhan (perkiraan). Namun, bagi orang yang mampu mengetahui arah kiblat secara pasti dan yakin, maka harus menghadap ke arahnya. Ulama Madzhab Hambali sepakat atas wajibnya menghadap ke arah Ka'bah (Jihatul Ka'bah) bagi orang yang tidak dapat melihatnya, bukan menghadap ke bangunan Ka'bah ('Ainul Ka'bah).

Masjid-masjid yang ditemukan tidak akurat arah kiblatnya ternyata memang belum menggunakan metode penentuan arah kiblat yang tepat yaitu metode taqribi dan metode tahqiqi. Harapan kita ke depan hendaknya para pengelola/pengurus masjid lebih serius lagi memperhatikan akurasi arah kiblatnya bila ingin merenovasi atau membangun masjid baru.

\section{Penutup}

\section{Kesimpulan}

Beberapa cara menentukan arah kiblat secara tepat diantaranya adalah:

a. Metode taqribi (Acuan perkiraan) dengan menggunakan alat pisau silet, kompas, busur derajat (rubu' Mujayyab), tongkat istiwa dan rashdul kiblat.

b. Metode tahqiqi (metode pengukuran yang akurat) dengan menggunakan teodolit, GPS (Global Positioning System) dan ilmu Segitiga Bola (Spherical Trigonometri).

Adapun cara masyarakat menentukan arah kiblat masjid-masjid di Kota Kendari dengan metode tradional menimbulkan akurasi arah kiblat di 14 masjid dari 20 masjid objek penelitian melenceng atau menyimpang dari arah kiblat yang seharusnya. 
Berdasarkan hasil penelitian tentang akurasi arah kiblat masjidmasjid di kota yang menunjukkan bahwa ada beberapa masjid yang sudah akurat arah kiblatnya dan ada juga beberapa masjid yang tidak akurat atau tepat arah kiblatnya. Yang akan dibahas adalah masjid-masjid yang akurasi arah kiblat tidak tepat. Ketidakakuratan arah kiblat beberapa masjid di kota Kendari disebabkan cara masyarakat menentukan arah kiblat yang tidak dapat dipertanggujawabkan. Terlihat dari hasil penelitian bahwa masjid yang tidak akurat arah kiblatnya yang pengukurannya bayangan matahari, arah barat dan hanya mengikuti arah masjid yang terdekat.

Berdasarkan pendapat empat imam mazhab di atas, hanya Imam Syafi'i yang mewajibkan menghadap ke bangunan seperti halnya orang Mekkah. Sedangkan tiga Imam lainnya membolehkan menghadap ka'bah secara dzan (perkiraan) bila tidak mengetahui arah kiblat secara pasti. Namun demikian, menurut hemat Peneliti, lebih baik berusaha semaksimal mungkin untuk mengarah ke kiblat secara tepat.

\section{Saran}

Bagi masjid yang tidak akurat atau tidak sesuai dengan arah kiblatnya harus diarahkab ke arah kiblat yang tepat, dengan cara bangunan masjid harus direhab atau direnovasi, namun hal ini menyulitkan karena memerlukan biaya yang sangat banyak. Maka langkah yang paling mudah adalah dengan mengubah shaf dengan biaya yang sangat murah, yang mana shaf harus diarahkan ke arak kiblat yang akurat atau sebenarnya, itulah langkah yang paling toleran dan sederhana.

Namun, seharusnya pemerintah yaitu Kementerian Agama Kota Kendari melakukan pengecekan ulang arah kiblat dan melakukan sosialisasi atau Surat Edaran tentang arah kiblat yang akurat agar arah 
kiblat masjid dapat akurat secara merata dan keraguan masyarakat terhadap arah kiblat masjid yang ada di Kota Kendari.

\section{Daftar Pustaka}

\section{Buku:}

Al-Jaziry, Abdur Rahman, 2004, Al-Fiqhu 'ala Madzahahibil Arba'ati, Daarul Hadits, al-Qahirah.

Azhari, Susiknan, 2007, Ilmu Falak Perjumpaan Khazanah Islam dan Sains Modern, Cet. Ke - 2, Suara Muhammadiyah, Yogyakarta.

Azhari, Susiknan, 2004, Ilmu Falak Teori dan Praktek, Cet.ke - 1, Suara Muhammadiyah, Yogyakarta.

Dahlan, Abdul Aziz, 2005, Ensiklopedia Silam, PT. Ichtiar Varu vann Hoeve, Jakarta.

Departemen Pendidikan Nasional, 2008, Kamus Besar bahasa Indonesia Pusat Bahasa, Cet. Ke - 4, PT. Gramedia Pustaka Utama, Jakarta.

Hambali, Slamet, Ilmu Falak I (Tentang Penentuan Awal Waktu Shalat dan Penentuan Arah Kiblat di Seluruh Dunia), t.th.

Hasanudin Z, Abidin, 2001, Geodesi Satelit, PT. Pradnya Paramita, Jakarta.

Izzuddin, Ahmad, 2012, Ilmu Falak Praktis : Metode Hisab-Rukyat Praktis dan Solusi Permasalahannya, Cet. Ke - 2, PT. Pustaka Rizki Putra, Semarang.

Izzuddin, Ahmad, 2012, Kajian Terhadap Metode-Metode Penentuan Arah Kiblat dan Akurasinya, Cet. Ke - 1, Kementerian Agama RI, Jakarta.

Jamil, A, 2009, Ilmu Falak Teori dan Aplikasih, Cet. I, Amzah, Jakarta.

Khazin, Muhyiddin, 2004, Ilmu Falak dalam Teori dan Praktek, Cet. Ke - 1, Buana Pustaka, Yogyakarta.

Maskufa, 2010, Ilmu Falak, Cet. Ke - 2, Gaung Persada Press, Jakarta.

Sugiono, 2009, Metode Penelitian Kuantitatif dan Kualitatif dan R\&D, Cet. VII, CV. Alfabeta, Jakarta. 
Supriatna, Encup, 2007, Hisab Rukyat dan Aplikasinya, PT. Refika Aditama, Bandung.

Tim Majelis Tarjih dan Tajdid Pimpinan Pusat Muhammadiyah, 2009, Pedoman Hisab Muhammadiyah, Cet. Ke - 2, Majelis Tarjih dan Tajdid Pimpinan Pusat Muhammadiyah, Yogyakarta.

Warson Munawwir, Achmad, 1997, Kamus al-Munawwir Arab-Indonesia Terlengkap, Cet. Ke -14, Pustaka Progressif, Yogyakarta.

Yaqub, Ali Mustafa, 2010, Kiblat Antara Bangunan dan Arah Ka'bah, Pustaka Darus-Sunnah, Jakarta.

\section{Hasil Penelitian/Tugas Akhir}

Husnul Mubarok, Muhammad, 2015, Pemikiran Ali Mustafa Yaqub Tentang Arah Kiblat, Skripsi, UIN Sunan Kalijaga, Yogyakarta.

Izzuddin, Ahmad, 2012, Metode Penetuan Arah Kiblat dan Akurasinya, AICIS, IAIN Sunan Ampel, Surabaya.

Khafid, 2009, Penentuan Arah Kiblat, Skripsi, Makalah Pelatihan Penentuan Arah Kiblat, Cibinong.

Wafa, Sirril, dkk, 2015, Akurasi Arah Kiblat Masjid dan Mushallah di Wilayah Ciputat", Laporan Penelitian, Fakultas Syariah dan Hukum UIN Syarif Hidayatullah, Jakarta. 